\title{
Use efficiency of variable rate of nitrogen prescribed by optical sensor in corn ${ }^{1}$
}

\author{
Jardes Bragagnolo², Telmo Jorge Carneiro Amado ${ }^{3}$, Rafael Pivotto Bortolotto ${ }^{4 *}$
}

$10.1590 / 0034-737 X 201663010014$

\begin{abstract}
The efficiency of nitrogen fertilizer in corn is usually low, negatively affecting plant nutrition, the economic return, and the environment. In this context, a variable rate of nitrogen, prescribed by crop sensors, has been proposed as an alternative to the uniform rate of nitrogen traditionally used by farmers. This study tested the hypothesis that variable rate of nitrogen, prescribed by optical sensor, increases the nitrogen use efficiency and grain yield as compared to uniform rate of nitrogen. The following treatments were evaluated: $0 ; 70 ; 140$; and $210 \mathrm{~kg} \mathrm{ha}^{-1}$ under uniform rate of nitrogen, and $140 \mathrm{~kg} \mathrm{ha}^{-1}$ under variable rate of nitrogen. The nitrogen source was urea applied on the soil surface using a distributor equipped with the crop sensor. In this study, the grain yield ranged from 10.2 to $15.5 \mathrm{Mg} \mathrm{ha}^{-1}$, with linear response to nitrogen rates. The variable rate of nitrogen increased by 11.8 and $32.6 \%$ the nitrogen uptake and nitrogen use efficiency, respectively, compared to the uniform rate of nitrogen. However, no significant increase in grain yield was observed, indicating that the major benefit of the variable rate of nitrogen was reducing the risk of environmental impact of fertilizer.
\end{abstract}

Key words: site-specific management, crop sensor, precision agriculture, soil fertility.

\section{RESUMO}

\section{Eficiência de uso da dose variada de nitrogênio prescrita por sensor óptico em milho}

A eficiência da fertilização nitrogenada no milho geralmente é baixa, impactando negativamente a nutrição de plantas, o retorno econômico e o meio ambiente. A dose variada de nitrogênio, prescrita por sensores de planta, tem sido proposta em substituição à dose uniforme de nitrogênio tradicionalmente utilizada pelos agricultores. Este estudo testou a hipótese de que a dose variável de nitrogênio, baseada no sensor óptico, aumenta a eficiência de uso do nitrogênio e a produtividade de grãos em relação à dose variável de nitrogênio. Os seguintes tratamentos foram avaliados: 0 , 70,140 e $210 \mathrm{~kg} \mathrm{ha}^{-1}$ a dose uniforme de nitrogênio e $140 \mathrm{~kg} \mathrm{ha}^{-1}$ a dose variável de nitrogênio. A fonte de $\mathrm{N}$ foi ureia aplicada a lanço com um distribuidor de fertilizantes acoplado ao sensor óptico de plantas. Neste estudo, a produtividade de grãos variou de 10,2 a 15,5 $\mathrm{Mg} \mathrm{ha}^{-1}$, com resposta linear às doses de nitrogênio. A dose variável de nitrogênio proporcionou aumento de 11,8 e 32,6\% na quantidade de nitrogênio absorvido e na eficiência de uso do nitrogênio, respectivamente, em comparação à dose uniforme de nitrogênio. Porém, o incremento na produtividade não foi significativo, indicando que o principal efeito da dose variada de nitrogênio foi a redução do risco de impacto ambiental do fertilizante.

Palavras-chave: manejo sítio-específico, sensor óptico de planta, agricultura de precisão, fertilidade do solo.

\footnotetext{
Submitted on 12/18/2014 and approved on 10/27/2015.

${ }^{1}$ This paper is part of the first author's doctorate thesis.

${ }^{2}$ Universidade Regional Integrada do Alto Uruguai e das Missões, Departamento de Ciências Agrárias, Erechim, Rio Grande do Sul, Brasil. jardesb@yahoo.com.br

${ }^{3}$ Universidade Federal de Santa Maria, Departamento de Solos, Santa Maria, Rio Grande do Sul, Brasil. florestatel@ hotmail.com

${ }^{4}$ Universidade de Cruz Alta, Centro de Ciências da Saúde e Agrárias, Cruz Alta, Rio Grande do Sul, Brasil. rafaelpbortolotto@gmail.com

* Corresponding author: rafaelpbortolotto@gmail.com
} 


\section{INTRODUCTION}

Corn (Zea mays L.) is the main cereal grown in Brazil, with an area over 15 million ha. In the 2013/14 crop season, the Brazilian corn production reached 79.9 million tons (CONAB, 2014), representing an increase in production of $3 \%$ per year in the last decade, while cropland had just a slight increase $(0.4 \%)$ (Miranda et al., 2012). Therefore, the recent increase in Brazilian corn production was mainly associated with yield gain, reflecting the improvement in crop management, especially nitrogen $(\mathrm{N})$ fertilization management.

Increasing the rate of $\mathrm{N}$ fertilization, may intensify the environmental impact, since $\mathrm{N}$ fertilization efficiency worldwide is low and stood around 33\% (Raun \& Johnson, 1999). Currently, in southern Brazil, $\mathrm{N}$ fertilization recommendation is based on the content of soil organic matter (SOM), yield goal, and previous cash crop or cover crop in the field (Amado et al., 2002). However, the spatial variability of soil properties that enhance the availability of N to plants, such as, SOM (Casa et al., 2011), soil nitrate (Hurtado et al., 2009; Casa et al., 2011), and soil water storage (Santi et al., 2012), are not taken into consideration. Thus, the same field may have different optimum $\mathrm{N}$ fertilization rates (Raun et al., 2002; Portz et al., 2012) and, in such case, suggesting that uniform rate of $\mathrm{N}$ (URN) could not properly fit for the whole area, resulting in under or overfertilized areas (Hurtado et al., 2009; Nogara Neto et al., 2011). Therefore, the spatial variability of soil and plant attributes in the field are challenges to obtain high $\mathrm{N}$ use efficiency (NUE) and crop yield.

The variable rate of $\mathrm{N}$ (VRN) adjusts the fertilizer input according to the plant nutritional status. In this case, one most frequently used fertilizer prescription is increasing the $\mathrm{N}$ rate in plants with low nutritional status, where there is a higher probability of response to the input. This strategy commonly results in NUE optimization (Raun et al., 2005; Singh et al., 2006, Bragagnolo et al., 2013b). In addition, the VRN can promote increases in plant $\mathrm{N}$ uptake and, consequently, reduces the risk of $\mathrm{N}$ losses by leaching, runoff, and volatilization (Fixen et al., 2005).

The crop sensors, based on optical spectroscopy, use the principle of reflectance in wavelengths of the visible and near infrared spectrum on the leaf tissues of the plants and can be used for the $\mathrm{N}$ fertilization prescription (Raun et al., 2005; Povh et al., 2008; Grohs et al., 2009; Jasper et al., 2009; Amaral \& Molin, 2011; Portz et al., 2012; Bragagnolo et al., 2013a, b).

In Brazil, the information about the use of crop sensors in $\mathrm{N}$ fertilization is scarce. This study tested the hypothesis that the use of the optical spectroscopy sensor increases the efficiency of corn $\mathrm{N}$ fertilization. The specific objectives were: a) to evaluate the efficiency of the sensor to capture the corn nutritional status in different growth stages; and b) to compare NUE and corn grain yield under VRN and URN fertilization strategies.

\section{MATERIAL AND METHODS}

The experimental area has coordinates 28 31'36" S and 52 47' 45"W, with 550 m altitude, in Não-Me-Toque county, $\mathrm{RS}$, Brazil. The climate is Cfa, humid subtropical, according to Koppen (1948) classification, with frequent incidences of short drought during the summer. The average rainfall is $1700 \mathrm{~mm} \mathrm{yr}^{-1}$ evenly distributed through the year, with an average annual temperature of $19.5^{\circ} \mathrm{C}$.

This study was conducted in a rainfed cropland in 2010/2011 that had favorable conditions of precipitation during corn growth period, with a total volume of 1048 $\mathrm{mm}$ and even distribution (Figure 1).

The soil of the experimental area is a distrophic Red Oxisol (Typic Hapludox) (Soil Survey Staff, 2010) or Latossolo Vermelho distrófico (Embrapa, 2006), with gentle slopes. Prior to the establishment of this experiment, the area was managed under a continuous no-till system for fifteen years. The particle size and chemical soil characteristics in the beginning of the experiment are shown in Table 1.

Corn was sown on September $10^{\text {th }}, 2010$, on oat straw residue, with spacing $0.50 \mathrm{~m}$. Pioneer hybrid 30F53 corn was used with an estimated plant population of $67,000 \mathrm{ha}^{-}$ 1. The fertilization at planting consisted of $30 \mathrm{~kg} \mathrm{ha}^{-1}$ of $\mathrm{N}$, $78 \mathrm{~kg} \mathrm{ha}^{-1}$ of $\mathrm{P}_{2} \mathrm{O}_{2}$, and $69 \mathrm{~kg} \mathrm{ha}^{-1}$ of $\mathrm{K}_{2} \mathrm{O}$. The source of $\mathrm{N}$ was urea ( $45 \%$ of $\mathrm{N})$, for phosphorus $(\mathrm{P})$, it was triple superphosphate $\left(21 \%\right.$ of $\left.\mathrm{P}_{2} \mathrm{O}_{5}\right)$, and for potassium $(\mathrm{K})$ potassium chloride $\left(60 \%\right.$ of $\left.\mathrm{K}_{2} \mathrm{O}\right)$ was used.

The experiment was in a randomized block design with three replications, with treatments arranged in linear strips. The plots had dimensions of $36 \times 300 \mathrm{~m}$ with a total experimental area of $10,800 \mathrm{~m}^{2}$. The treatments consisted of the following rates of $\mathrm{N}$ and fertilization strategies: 1) $0 \mathrm{~kg}$ ha $^{-1}$ (control); 2) $70 \mathrm{~kg} \mathrm{ha}^{-1}$ uniform rate (70URN); 3) $140 \mathrm{~kg}$ $\mathrm{ha}^{-1}$ uniform rate (140URN); 4) $140 \mathrm{~kg} \mathrm{ha}^{-1}$ variable rate, based on crop sensor (140VRN); and 5) $210 \mathrm{~kg} \mathrm{ha}^{-1}$ uniform rate (210URN). Urea was applied by a distributor equipped with double disk centrifuge under conditions of high soil moisture. The $\mathrm{N}$ rate selected to compare the fertilization strategies of URN and VRN (140 $\left.\mathrm{kg} \mathrm{ha}^{-1}\right)$ was recommended regionally (CQFS-RS/SC, 2004) for an expected yield between 8-9 Mg ha ${ }^{-1}$, for soils with 2.6 to $5.0 \%$ levels of SOM with previous grasse cultivation.

The $\mathrm{N}$ fertilizer treatments with rates higher than $70 \mathrm{~kg}$ $\mathrm{ha}^{-1}$ were split into three applications as follows: $30 \mathrm{~kg} \mathrm{ha}^{-}$ ${ }^{1}$ at planting; $40 \mathrm{~kg} \mathrm{ha}^{-1}$ applied at V4 corn stage with four fully expanded leaves, using the Zadoks Scale; $70 \mathrm{~kg}$ ha${ }^{1}$ (140URN and 140VRN) and $140 \mathrm{~kg} \mathrm{ha}^{-1}$ (210URN) applied at V8 stage. 
The plant attributes evaluated, in the phenological stages V4, V6, V8, V10, V12, and tasseling (VT), were: N content of aboveground biomass, total $\mathrm{N}$ uptake, dry matter (DM) yield, SPAD index, and vegetation index (VI) determined by the optical sensor. For the plant samples, a transect with seven georeferenced points, with regular spacing of $40 \mathrm{~m}$, was used. In order to determine the DM production, plants were harvested within a $2 \mathrm{~m}$ radius around the georeferenced point. The determination of plant $\mathrm{N}$ content was made by micro Kjeldahl digestion, according to the methodology described in Tedesco et al. (1995). For SPAD index was used five plants per georeferenced point, according to the methodology described by Argenta et al. (2001).

In treatment 140VRN, based on VI determined with the optical sensor, the rate of $\mathrm{N}$ fertilizer was established by means of a YARA algorithm (Yara International ASA, Duelmen, Germany). The ensemble fertilizer distributor and crop sensor comprised of two optical sensors attached to the top of the tractor cabin (right and left side), at approximately $3.8 \mathrm{~m}$ above the ground, making the reading of an area with a width of $3.0 \mathrm{~m}$ on each side of the tractor, allowing the device to read approximately $33 \%$ of the plants present in the experiment. The angle formed by light beam from the xenon transmitter and soil surface was between 50 to $66^{\circ}$.
The optical sensor xenon transmitters comprised of multispectral waves (650 to $1100 \mathrm{~nm}$ ) of high intensity, and has two photodiode receptors used to determine the VI, based on the ratio of the spectral reflectance in the wavelengths 730 and $760 \mathrm{~nm}$ calculated by equation (1) (Jasper et al., 2009):

$\mathrm{VI}=\left(\ln \mathrm{R}_{760}-\ln \mathrm{R}_{730}\right) \times 100$

Where: VI is the vegetation index; $\mathrm{R}_{760}$ is the reflectance at wavelength $760 \mathrm{~nm} ; \mathrm{R}_{730}$ is the reflectance at wavelength $730 \mathrm{~nm}$

In treatment $140 \mathrm{VRN}$, the fertilizer was applied dividing into two phases. The first was carried out to determine the average VI (64.7) of the plants in the area at V8 crop stage, for which a reference $\mathrm{N}$ rate of $70 \mathrm{~kg} \mathrm{ha}^{-1}$ was assigned. Then, at the second phase, a new determination of VI and a real-time $\mathrm{N}$ prescription rate was transmitted to the controller and in sequence to the centrifugal distributor disks for fertilizer application. The fertilizer distribution width was set to $21 \mathrm{~m}$, with $3 \mathrm{~m}$ of overlap between the two passes of the equipment, totalizing $36 \mathrm{~m}$ of plot width.

The data obtained from the optical sensor were transferred to a geographical information system (Campeiro 7.0, Giotto, 2011). Afterwards, the average VI readings and the prescribed $\mathrm{N}$ rate were determined in a

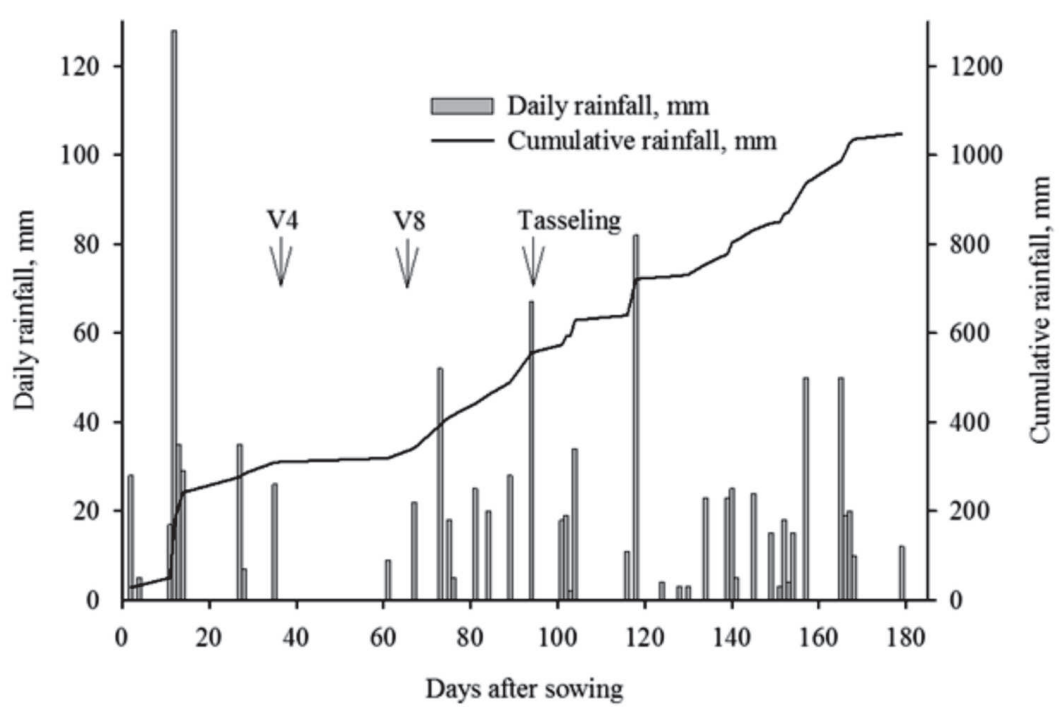

Figure 1: Daily and cumulative rainfall during the corn cycle in the 2010/2011 harvest. *V4= corn phenological stage with four fully expanded leaves using the Zadoks Scale; V8= corn phenological stage with eight fully expanded leaves using the Zadoks Scale.

Table 1: Analysis of particle size and chemical characteristics of the soil in the experimental area of the $0-0.10 \mathrm{~m}$ layer

\begin{tabular}{|c|c|c|c|c|c|c|c|c|}
\hline Clay $^{1}$ & $\mathrm{pH} \mathrm{H}_{2} \mathrm{O}^{2}$ & SOM $^{3}$ & $\mathbf{P}^{4}$ & $\mathbf{K}^{4}$ & $\mathrm{Al}^{5}$ & $\mathrm{Ca}^{5}$ & $\mathrm{Mg}^{5}$ & CTC \\
\hline $\mathrm{g} \mathrm{kg}^{-1}$ & & $\%$ & $\mathrm{mg} \mathrm{dm}^{-3}$ & \multicolumn{5}{|c|}{$\mathrm{cmol}_{\mathrm{c}} \mathrm{dm}^{-3}$} \\
\hline 550 & 5.8 & 3.8 & 12.3 & 0,64 & 0.0 & 7.0 & 2.2 & 14.0 \\
\hline
\end{tabular}

${ }^{1}$ Determined by densitometry; ${ }^{2}$ determined by potentiometric; ${ }^{3}$ soil organic matter determined by the Walkley-Black method; ${ }^{4}$ determined by Mehlich ${ }^{-1}$ solution; ${ }^{5}$ determined by extraction with $\mathrm{KCl}\left(1 \mathrm{~mol} \mathrm{~L}^{-1}\right)$. 
radius of $10 \mathrm{~m}$ around each georeferenced point of the transect. For the evaluation of the efficiency of the prescribed $\mathrm{N}$ rates, the following classification was used: low $\left(64.5 \pm 2.2 \mathrm{~kg} \mathrm{ha}^{-1}\right)$, medium $\left(70.4 \pm 0.3 \mathrm{~kg} \mathrm{ha}^{-1}\right)$, and high $\left(78.1 \pm 4.0 \mathrm{~kg} \mathrm{ha}^{-1}\right)$, with four replications per class.

Data for corn grain yield were obtained by manual harvesting of two rows with two linear meters $\left(2 \mathrm{~m}^{2}\right)$ around each georeferenced point of the transect. Each plot was harvested separately with the MF $34{ }^{\circledR}$ combine equipped with a yield sensor, and the total plot grain yield was weighted separately. The grain yield results were adjusted to $13.0 \%$ moisture.

To determine the NUE, the formula for $\mathrm{N}$ recovery efficiency (NRE) and $\mathrm{N}$ agronomic efficiency (NAE) were used according to the methodology described in equation (2) and (3) according to Cassman et al. (2002) and Dobermann (2005):

$\mathrm{NRE}=\left(\mathrm{N}_{\mathrm{N}}-\mathrm{N}_{0}\right) / \mathrm{R}_{\mathrm{N}}$

Where: $\mathrm{N}_{\mathrm{N}}$ is $\mathrm{N}$ uptake at flowering $\left(\mathrm{kg} \mathrm{ha}^{-1}\right)$ under the evaluated $\mathrm{N}$ rate; $\mathrm{N}_{0}$ is $\mathrm{N}$ uptake at flowering $\left(\mathrm{kg} \mathrm{ha}^{-1}\right)$ under the control treatment (without $\mathrm{N}$ ); $\mathrm{R}_{\mathrm{N}}$ is the evaluated $\mathrm{N}$ rate $\left(\mathrm{kg} \mathrm{ha}^{-1}\right)$.

$\mathrm{NAE}=\left(\mathrm{Y}_{\mathrm{N}}-\mathrm{Y}_{0}\right) / \mathrm{R}_{\mathrm{N}}$

Where: $\mathrm{Y}_{\mathrm{N}}$ is corn grain yield $\left(\mathrm{kg} \mathrm{ha}^{-1}\right)$ of treatment with the tested rate; $\mathrm{Y}_{0}$ is corn grain yield $\left(\mathrm{kg} \mathrm{ha}^{-1}\right)$ of control treatment (without $\mathrm{N}$ ); $\mathrm{R}_{\mathrm{N}}$ is the evaluated $\mathrm{N}$ rate $\left(\mathrm{kg} \mathrm{ha}^{-1}\right)$.

The determination of gross income, for every $60 \mathrm{~kg}$ bag of corn, was worth R $\$ 25.00$ at the time of harvest (COTRIJAL, 2011).

The experimental results were submitted to descriptive analysis of variance. The averages were compared by the Tukey test $(\mathrm{P}<0.05)$, followed by polynomial regression using the statistical package SISVAR 4.0 (Ferreira, 2000).

\section{RESULTS AND DISCUSSION}

The plant attributes related to $\mathrm{N}$ nutritional status of corn, assessed at VT, were directly related to the rate of $\mathrm{N}$ fertilizer, providing the increased $\mathrm{N}$ content, $\mathrm{N}$ uptake, the SPAD Index, VI determined by the optical sensor, and corn grain yield, as expected. However, the DM yield did not show correlation with corn grain yield (Table 2).

This was an important prerequisite for evaluating the crop sensor and VRN efficiency. Therefore, the treatment with the highest $\mathrm{N}$ rate (210URN) increased by $56 \%$ the plant $\mathrm{N}$ uptake and by $50 \%$ the plant $\mathrm{N}$ content, which is important for cell division and expansion, besides being the main component for the chlorophyll molecules responsible for photosynthesis, driving the plant accumulation of carbohydrates and plant growth (Malavolta, 1997; Lobell, 2007).
The control treatment, although without $\mathrm{N}$ fertilizer input, had high $\mathrm{N}$ uptake (117 $\left.\mathrm{kg} \mathrm{ha}^{-1}\right)$ and corn DM yield (10.1 $\mathrm{Mg} \mathrm{ha}^{-1}$ ) (Table 2). This result is associated with continuous no-till with cover crops and crop rotation adopted in this cropland for the last 15 years, with the favorable climatic conditions for corn growth (Figure 1). Therefore, even the control treatment achieved a high grain yield (10.2 $\mathrm{Mg} \mathrm{ha}^{-1}$ ) (Table 2). Previously, Lázaro et al. (2013), in southern Brazil, also reported that even without $\mathrm{N}$ fertilizer input, under favorable climatic conditions and good management practices, the grain yield achieved 10 $\mathrm{Mg} \mathrm{ha}^{-1}$.

The N content of the plant, at VT corn stage, regardless of treatment, fell within or above the range considered critical (1.0 to $1.3 \%$ ) (Amado et al., 2002). However, the highest grain yield was obtained with $\mathrm{N}$ content of plants ranging from 1.6 to $1.8 \%$, therefore higher than those considered critical (Table 2).

The SPAD Index presents a positive linear relationship with the $\mathrm{N}$ rates (Table 2), agreeing with the report by Jakelaitis et al. (2005). Only the control and 70URN treatments showed, at VT stage, the SPAD index the value 57.1 proposed as critical by Argenta et al. (2004). However, the highest grain yield $\left(15.6 \mathrm{Mg} \mathrm{ha}^{-1}\right)$ was achieved with SPAD index (59.4) slightly higher than the critical value.

The $\mathrm{N}$ fertilization rate had an influence on the nitrogen content of the plant and on grain yield with linear effect first-degree up to $210 \mathrm{~kg} \mathrm{ha}^{-1}$, indicating that if higher $\mathrm{N}$ rates were investigated, it could still have an increase in grain yield (Table 2). The treatment with the highest $\mathrm{N}$ rate (210URN) showed an increase of $5.3 \mathrm{Mg} \mathrm{ha}^{-1}(52.0 \%)$ in grain yield compared to the control (Table 2). The high response to $\mathrm{N}$ fertilization, can be partly attributed to the favorable climatic conditions for corn growth, expressed by the satisfactory precipitation in critical growth stages (Figure 1), abundant light, and cool nights, in addition to soil quality (Table 1) and a hybrid corn with high yield potential.

The efficiency of VRN fertilizer strategy depends, among other factors, on the capacity of the crop sensor to capture, in an early development stage, the different nutritional status of corn plants in the cropland.

In this study, the VI readings obtained by the optical sensor were closely related to the amount of $\mathrm{N}$ uptake and corn DM yield (Figure 2a, b). Previously, Mayfield \& Trengove (2009) reported a high correlation between the VI readings and the wheat $\mathrm{N}$ uptake. Already, Portz et al. (2012) reported a correlation of the VI readings with the $\mathrm{N}$ uptake and sugarcane DM yield. In order to prescribe the VRN, the crop sensor was utilized in this study in V8 stage, at which the sensor had a high sensitivity to the plant attributes that drives the $\mathrm{N}$ demand. 
In Figure $2 \mathrm{a}$ and $\mathrm{b}$, it can be observed that VI increased exponentially as a function of both the amount of $\mathrm{N}$ uptake and the corn DM yield, and that at the advanced crop growth stages there was a sensibility loss in the sensor (saturation effect). In this study, the saturation effect was intensified when the amount of plant $\mathrm{N}$ uptake was higher than $70 \mathrm{~kg} \mathrm{ha}^{-1}$ and the corn DM yield exceeded $2,500 \mathrm{~kg}$ $\mathrm{ha}^{-1}$, corresponding either to V10 or to more advanced

Table 2: Plant attributes evaluated at the tasseling stage of corn for nitrogen fertilizer treatments

\begin{tabular}{lccccc}
\hline Treatments & $\begin{array}{c}\text { N content } \\
\mathbf{\%}\end{array}$ & $\begin{array}{c}\mathbf{N} \text { uptake } \\
\mathbf{k g ~ h a}^{-\mathbf{1}}\end{array}$ & $\begin{array}{c}\mathbf{D M} \\
\mathbf{k g ~ h a}^{-\mathbf{1}}\end{array}$ & SPAD & $\begin{array}{c}\text { Grain yield } \\
\mathbf{k g ~ h a}^{-1}\end{array}$ \\
\hline $\mathrm{T}$ & $1.2 \mathrm{~d}$ & $117.0 \mathrm{c}$ & $10.11 \mathrm{ab}$ & $51.2 \mathrm{~d}$ & $10.231 \mathrm{c}$ \\
$70 \mathrm{URN}$ & $1.3 \mathrm{c}$ & $109.9 \mathrm{c}$ & $8.76 \mathrm{c}$ & $54.5 \mathrm{c}$ & $11.125 \mathrm{c}$ \\
$140 \mathrm{URN}$ & $1.6 \mathrm{~b}$ & $163.3 \mathrm{~b}$ & $10.42 \mathrm{a}$ & $57.1 \mathrm{~b}$ & $13.743 \mathrm{~b}$ \\
$140 \mathrm{VRN}$ & $1.7 \mathrm{ab}$ & $182.6 \mathrm{a}$ & $10.18 \mathrm{ab}$ & $57.5 \mathrm{ab}$ & $14.887 \mathrm{ab}$ \\
$210 \mathrm{URN}$ & $1.8 \mathrm{a}$ & $177.2 \mathrm{ab}$ & $9.56 \mathrm{ab}$ & $59.4 \mathrm{a}$ & $15.564 \mathrm{a}$ \\
Equation & $\mathrm{y}=1.17+0.003 \mathrm{x}$ & $\mathrm{y}=108.99+0.366 \mathrm{x}$ & $\mathrm{ns}$ & $\mathrm{y}=51.52+0.039 \mathrm{x}$ & $\mathrm{y}=9.97+28.01 \mathrm{x}$ \\
$\mathrm{R}^{2}$ & 0.91 & 0.64 & $\mathrm{~ns}$ & 0.98 & 0.91 \\
$\mathrm{P}$ & 0.0076 & 0.0496 & $\mathrm{~ns}$ & 0.0006 & 0.0104 \\
\hline
\end{tabular}

Averages followed by the same letter in the column do not differ by Tukey test at $5 \%$ probability; ns $=$ not significant; $\mathrm{T}=0 \mathrm{~kg}$ ha ${ }^{-1} \mathrm{~N}$; URN = Uniform rate of $\mathrm{N} ; \mathrm{VRN}=$ Variable rate of $\mathrm{N} ; \mathrm{R}^{2}=$ Coefficient of determination; $\mathrm{P}=$ level of significance calculated by $\mathrm{t}$ test; $\mathrm{DM}=\mathrm{Dry}$ matter; $\mathrm{SPAD}=\mathrm{SPAD}$ index; $\mathrm{N}$ content $(\%)=\mathrm{N}$ content in plant tissue; $\mathrm{N}$ uptake $\mathrm{kg}$ ha $^{-1}=\mathrm{N}$ in dry matter; $\mathrm{SD}=\mathrm{Standard}$ Deviation; Grain yield $=$ corn grain yield manually collected from $2 \mathrm{~m}$ of rows.
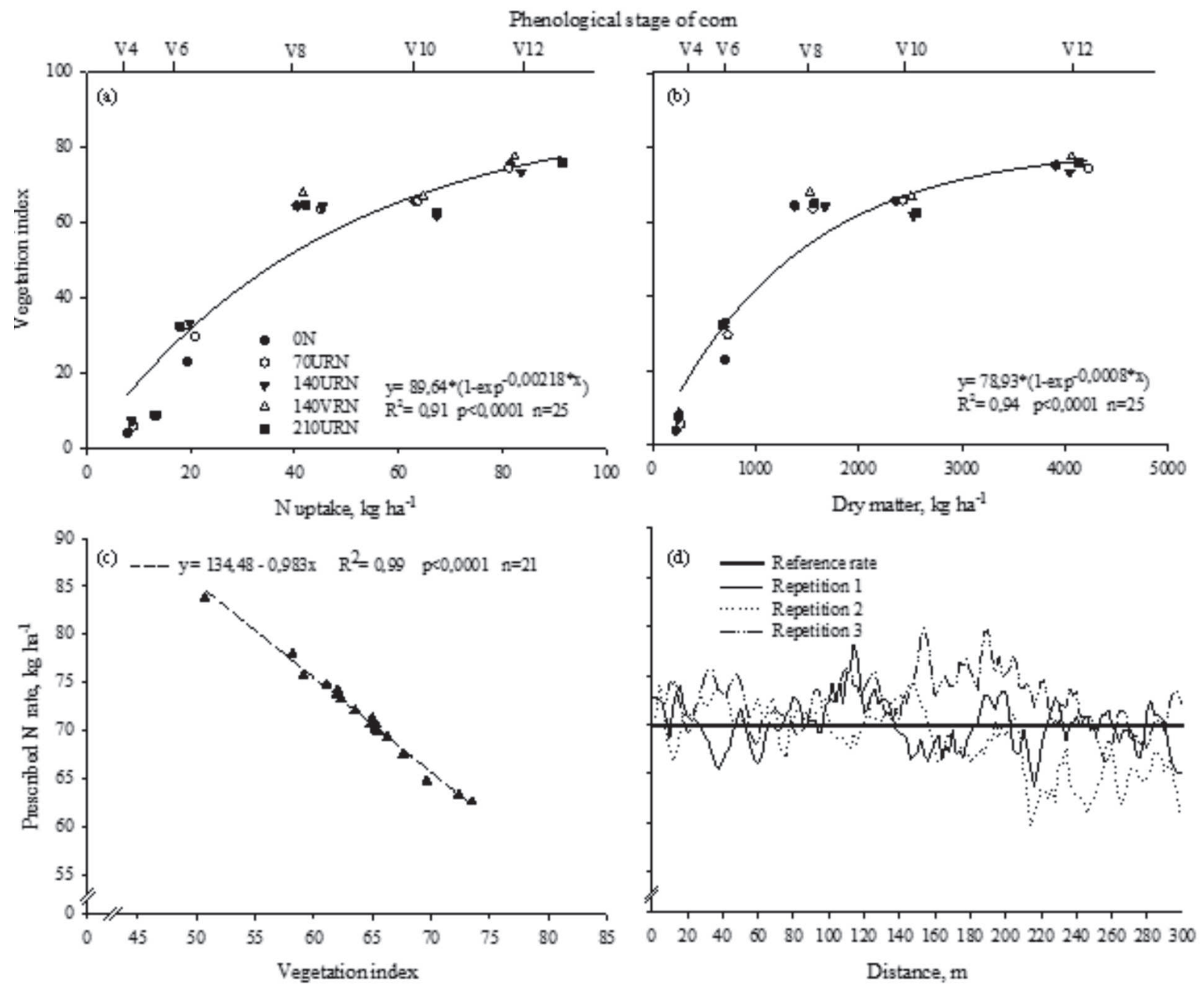

Figure 2: Vegetation index determined by the optical crop sensor corn with different amounts of nitrogen uptake (a) and dry matter yield (b); prescribed rate of nitrogen as a function of vegetation index determined by the optical sensor on the V8 stage of corn to the collection points of the vegetative attributes (c); and longitudinal distribution of varying rates in three applications (d). 
crop growth stages. Previously, Portz et al. (2012) reported the saturation effect of this optical sensor in sugarcane, when the amount of plant $\mathrm{N}$ uptake was higher than $40 \mathrm{~kg}$ $\mathrm{ha}^{-1}$ and the sugarcane DM yield was higher than $4,000 \mathrm{~kg}$ $\mathrm{ha}^{-1}$. The saturation effect has also been reported for other types of crop sensors based on the optical spectrometry (Grohs et al., 2009; Portz et al., 2012).

Based on the VI readings of the optical sensor and the sampling of plants made at V8 crop stage, at each point of the transect (Figure 2c, d), the regression between the VI readings and the prescribed $\mathrm{N}$ rate was established (Figure 2c). In this case, the VRN ranged from 62 to $84 \mathrm{~kg} \mathrm{ha}^{-1}$, according to the corn $\mathrm{N}$ nutritional status (Figure 2c), while the $\mathrm{N}$ uptake by plants ranged from 36.7 to $52.5 \mathrm{~kg}$ $\mathrm{ha}^{-1}$ and the DM yield from 1,270 to $1,916 \mathrm{~kg} \mathrm{ha}^{-1}$.

Thus, plants that had lower VI were associated with $\mathrm{N}$ deficiency and lower DM yield, consequently, with a higher probability of response to fertilizer input, justifying this increase in $\mathrm{N}$ rate relative to the reference $\mathrm{N}$ rate $(70 \mathrm{~kg}$ ha $\left.{ }^{1}\right)$ for that phenological crop stage. In contrast, plants with higher VI, indicated plants well supplied with $\mathrm{N}$ and with high DM yield (Figure 2c, d), and, therefore, less likely to respond to $\mathrm{N}$ fertilization, justifying the reduction in the reference $\mathrm{N}$ rate.

Previously, Mayfield \& Trengove (2009) reported that for a reference $\mathrm{N}$ rate of $33 \mathrm{~kg} \mathrm{ha}^{-1}$ in wheat, the prescribed $\mathrm{N}$ rates were in the range of 20 to $52 \mathrm{~kg} \mathrm{ha}^{-1}$, while the plant $\mathrm{N}$ uptake ranged from 69 to $118 \mathrm{~kg} \mathrm{ha}^{-1}$, and DM yield from 1,510 to $3,050 \mathrm{~kg} \mathrm{ha}^{-1}$.

In this study, only $9.7 \%$ of the prescribed $\mathrm{N}$ rates by the crop sensor coincided with the reference $\mathrm{N}$ rate, while $36.9 \%$ of the prescribed $\mathrm{N}$ rates were lower than the reference and 53.4\% were higher (Figure 2d). Repetition 3 had the lowest VI readings (Figure 2c, d) and, in that case, had a higher frequency of prescribed $\mathrm{N}$ rates above the reference $\mathrm{N}$ rate. On the other hand, in repetition 2, after $160 \mathrm{~m}$, there was a higher frequency of $\mathrm{N}$ rates below the reference $\mathrm{N}$ rate indicating the plot variability. Generally, in this study, the spatial variability, up to half the length of the plots, was lower than the rest of the plot, indicating that besides capturing differences among the replications, the sensor captured differences within the same repetition.

The spatial variability of the corn $\mathrm{N}$ nutritional status captured by the optical sensor is attributed to the intrinsic characteristics of the soil, microclimate, slope, and sitespecific management that affect crop development (Mayfield \& Trengove, 2009; Jorgensen \& Jorgensen, 2007).

A comparison of the fertilization strategies, URN and VRN, was based on the results shown in Table 2. The treatment, with VRN, had the plant $\mathrm{N}$ content, $\mathrm{N}$ uptake, and grain yield (manual harvesting at the transect points) increased numerically by $6.3,11.3$, and $8.3 \%$, respectively, in relation to URN, although statistically was significant only for the $\mathrm{N}$ uptake between the fertilization strategies.

Moreover, the VRN increased the NRE (equation 3) by approximately $14 \%$ compared to URN. The 140VRN, among all treatments investigated, provided the highest $\mathrm{N}$ uptake (182.6 $\mathrm{kg} \mathrm{ha}^{-1}$ ), however, not statistically differing from the 210URN treatment, which received an $\mathrm{N}$ rate $50 \%$ higher. This result is relevant, since the primary goal of fertilization is to increase the plant $\mathrm{N}$ uptake. Thus, the infield redistribution of $\mathrm{N}$ fertilizer rates, based on the spatial variability of the plant nutritional $\mathrm{N}$ status captured by the optical sensor, combined with a prescription of higher $\mathrm{N}$ rates to the plants with lower VI, was an effective strategy to increase the corn $\mathrm{N}$ uptake and NRE (Table 2). In this study, VRN had a numerical increase in grain yield of $1,144 \mathrm{~kg} \mathrm{ha}^{-1}$ (manual harvesting) in relation to URN, although, without statistical difference.

The histograms of the grain yield distribution, are shown in Figure $3 a$ and b. It was observed that the VRN promoted higher uniformity in corn grain yield, with reductions of 27 and $30 \%$ in standard deviations (SD) and coefficient of variation $(\mathrm{CV})$, respectively, compared to URN.

The frequency of grain yield $<12 \mathrm{Mg} \mathrm{ha}^{-1}$ was higher in URN than in VRN (Figure 3a, b). This result suggests that increasing $\mathrm{N}$ rates in plants with lower VI was an efficient strategy for correcting the poor nutritional $\mathrm{N}$ status of the corn diagnosed at V8 stage (Figure 2c). Moreover, the occurrence of over fertilized plants under URN treatment resulted in a $22 \%$ increase in the frequency of grain yield > $15 \mathrm{Mg} \mathrm{ha}^{-1}$ compared to those under VRN.

On the other hand, the fertilizer strategy of VRN resulted in an asymmetric distribution frequency of the grain yield classes with frequency concentration on the right side of the Figure, with an increase of $70 \%$ in the frequency of the yield classes in the range of $13-15 \mathrm{Mg}$ ha $^{-1}$ compared to URN. In summary, the main effect of VRN on grain yield was to decrease the frequency of less productive plants and, to some extent, of the highly productive ones.

In this study, the corn grain yield under VRN had a numerical increase of $6.5 \%$ compared to URN (data obtained with the combine) (Figure $3 \mathrm{a}, \mathrm{b}$ ), without statistical difference, similar to the results obtained with manual harvesting (8.3\%) (Table 2). Part of this result may be explained by the reduction of reference $\mathrm{N}$ rate $(70 \mathrm{~kg}$ $\mathrm{ha}^{-1}$ ) in VRN strategy, in a study in which there was a linear relationship of grain yield and $\mathrm{N}$ rate (Table 2 ). Thus, it was expected that some penalization in corn grain yield due to redistribution of $\mathrm{N}$ in VRN could happen. This reinforces the fact that to improve the efficiency of VRN, the reference $\mathrm{N}$ rate should be close to the maximum economic efficiency. 
The corn grain yield, NAE and gross income by class of $\mathrm{N}$ rate prescriptions in VRN strategy is shown in Figure 4. Thereby, the class of low $\mathrm{N}$ rate prescribed showed a grain yield $24.2 \%$ higher than URN, even with a $7.9 \%$ decrease in $\mathrm{N}$ rate. In addition, under VRN, there was an increase of $110.4 \%$ in NAE compared to URN. The high yield zone is able, at least in the short term, to sustain high grain yield even with some reduction in $\mathrm{N}$ rate. Cassman $e t$ al. (2002); Dobermann (2005); Snyder \& Bruulsema (2007); and Farinelli \& Lemos (2010) reported an increased NAE with the reduction in the $\mathrm{N}$ fertilizer rate.

The VRN strategy promoted an increase of $26.2 \%$ in gross income compared to URN. Therefore, the reduction in the $\mathrm{N}$ rate for plants with high VI at V8 crop stage was an efficient strategy, especially from an economic and environmental point of view.
In the class of high $\mathrm{N}$ rate prescribed, an increase of $11.6 \%$ in the $\mathrm{N}$ rate promoted an increase of $11.1 \%$ in grain yield compared to URN. Moreover, it was verified under VRN that NAE increased by $41.7 \%$ and gross income by $12.8 \%$ compared to URN. These results suggest a recovery from plant $\mathrm{N}$ deficiency diagnosed at V8 crop stage expressed by low VI readings. Tubaña et al. (2008) reported similar results for corn, and Mayfield \& Trengove (2009), for wheat.

In this study, the NAE was 25.0 and $32.0 \mathrm{~kg} \mathrm{~kg}^{-1}$ for URN and VRN, respectively (Figure 4). Thus, VRN strategy increased NAE by $32.6 \%$ compared to URN. Raun et al. (2005), Singh et al. (2006) and Maine et al. (2010) reported increases in NUE with VRN compared to URN. The NAE obtained under VRN strategy is slightly above $30 \mathrm{~kg} \mathrm{~kg}^{-1}$ and, as suggested by Dobermann et al. (2005),

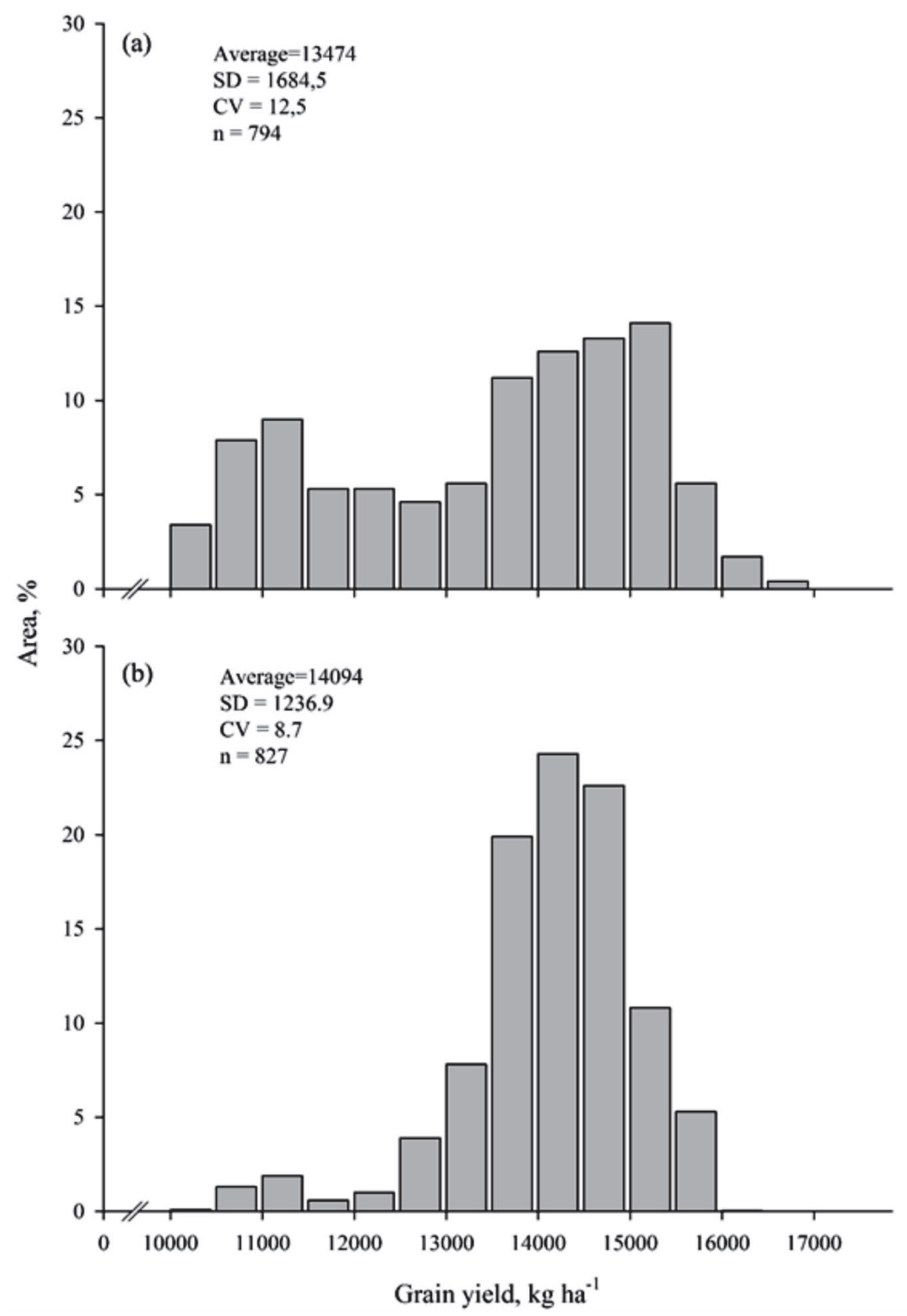

Figure 3: Distribution frequency histogram of corn grain yield acquired from the combine for uniform rate of $\mathrm{N}$ (a) and variable rate of $\mathrm{N}(\mathrm{b}) . \mathrm{SD}=$ Standard Deviation; $\mathrm{CV}=$ Coefficient of variation; $\mathrm{n}=$ number of observations. 


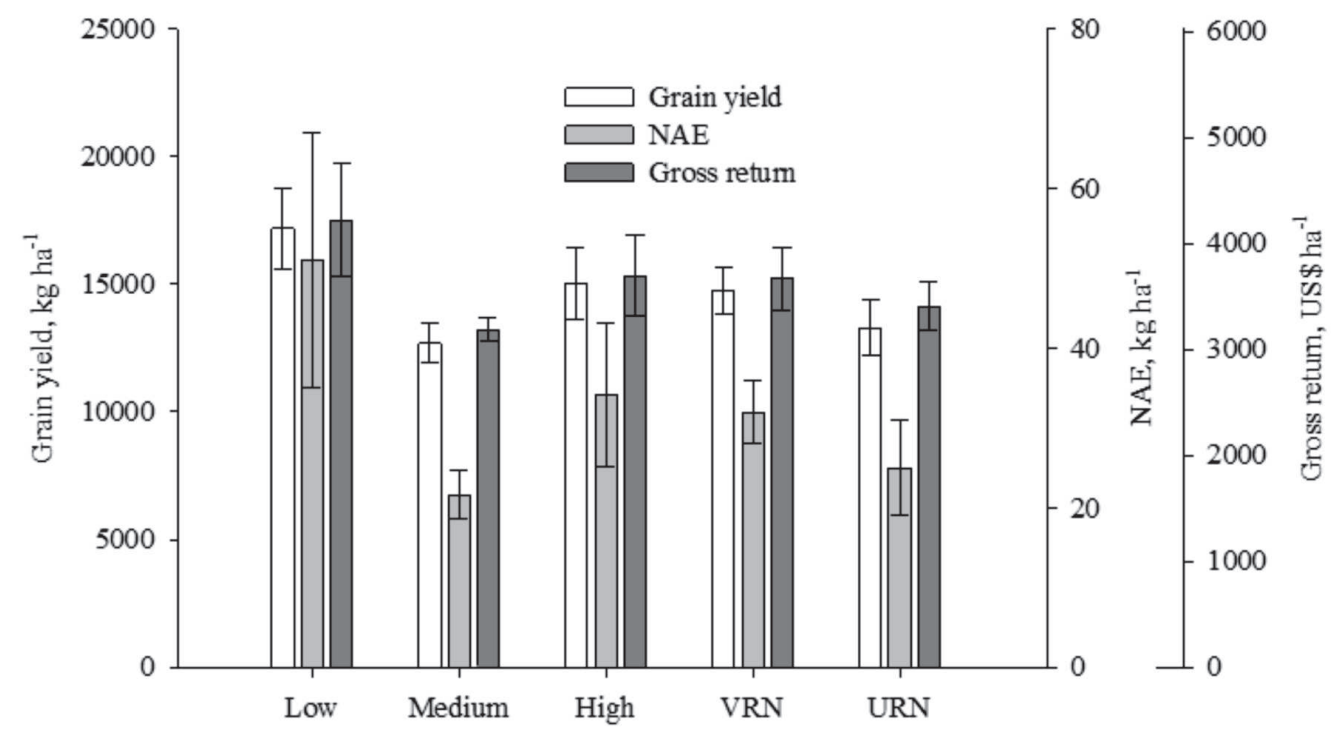

Figure 4: Corn grain yield, nitrogen agronomic efficiency and gross income in different classes of $\mathrm{N}$ rate at variable and uniform rate. $\mathrm{NAE}=$ Nitrogen agronomic efficiency; VRN = Variable rate of nitrogen; URN = Uniform rate of nitrogen.

is an indicator of a well $\mathrm{N}$ managed system. In addition, the VRN promoted an increase of $8.3 \%$ in gross income compared to URN.

For VRN to be an effective fertilizer strategy, two main conditions must be met: a) reduction in the $\mathrm{N}$ rate for plants with high VI, which should result in grain yield decreases that would not compromise the economic return; and b) increase in the $\mathrm{N}$ fertilizer rate for plants with low VI, which should result in increased crop grain yield over the rising cost of fertilizer input. The results obtained in this study suggest that both conditions were met, resulting in the increase of NAE and gross income compared to those obtained under URN. Furthermore, VRN was an efficient strategy from the environmental point of view, because it reduced the risks associated with $\mathrm{N}$ over fertilization.

\section{CONCLUSION}

The VI determined by the optical crop sensor used in this study was highly related to the nutritional status of corn valued at $\mathrm{N}$ uptake and dry matter yield.

The grain yield with VRN and URN strategies were similar, but increased plant $\mathrm{N}$ uptake and NUE, reducing the risk of environmental impact by $\mathrm{N}$ fertilization.

The VRN strategy proved efficient in the use of $\mathrm{N}$ by a reduction and increase of $\mathrm{N}$ rate prescribed by the optical sensor according to the nutritional status of the culture.

\section{REFERENCES}

Amado TJC, Mielniczuck J \& Aita C (2002) Recomendação de adubação nitrogenada para o milho no RS e SC adaptada ao uso de culturas de cobertura do solo, sob sistema de plantio direto. Revista Brasileira de Ciência do Solo, 26:241-248.
Amaral LR \& Molin JP (2011) Sensor óptico no auxílio à recomendação de adubação nitrogenada em cana de açúcar. Pesquisa Agropecuária Brasileira, 46:1633-1642.

Argenta G, Silva PRF \& Bortolini CG (2001) Clorofila na folha como indicador do nível de nitrogênio em cereais. Ciência Rural, 31:715-722.

Argenta G, Silva PRF \& Sangoi L (2004) Leaf relative chlorophyll content as an indicator parameter to predict nitrogen fertilization in maize. Ciência Rural, 34:1379-1387.

Bragagnolo J, Amado TJC, Nicoloso RS, Jasper J, Kunz J \& Teixeira TG (2013a) Optical crop sensor for variable-rate nitrogen fertilization in corn: I. Plant nutrition and dry matter production. Revista Brasileira de Ciência do Solo, 37:12881298.

Bragagnolo J, Amado TJC, Nicoloso RS, Santi AL, Fiorin JE \& Tabaldi F (2013b) Optical crop sensor for variable-rate nitrogen fertilization in corn: II. Indices of fertilizer efficiency and corn yield. Revista Brasileira de Ciência do Solo, 37:1299-1309.

Casa R, Cavalieri A \& Locascio B (2011) Nitrogen fertilization management in precision agriculture: A preliminary application example on maize. Italian Journal of Agronomy, 6:23-27.

Cassman KG, Dobermann A \& Walters DT (2002) Nitrogen use efficiency, and nitrogen management. Ambio, 31:132-144.

CONAB - Companhia Nacional de Abastecimento (2014) Acompanhamento da safra brasileira de grãos 2013/2014. Décimo segundo levantamento, Setembro/2014. Companhia Nacional de Abastecimento. Brasília. Disponível em: < www.conab.gov.br >. Acessado em: 12 de outubro de 2014.

CQFS-RS/SC - Comissão de Química e Fertilidade do Solo (2004) Recomendações de adubação e calagem para os estados do Rio Grande do Sul e Santa Catarina. 10 a ed. Comissão de Química e Fertilidade do Solo, Porto Alegre. 400p.

COTRIJAL - Cotrijal Cooperativa Agropecuária e Industrial (2011) Disponível em: <http://www.cotrijal.com.br>. Acessado em: 30 de fevereiro de 2011.

Dobermann A (2005) Nitrogen Use Efficiency - State of the Art. In: IFA International Workshop on Enhanced-Efficiency Fertilizers. Frankfurt, Germany. p.28-30. 
Embrapa (2006) Sistema brasileiro de classificação de solos. $2^{\text {a }}$ ed Rio de Janeiro, Centro Nacional de Pesquisa de Solos. 306p.

Farinelli R \& Lemos LB (2010) Produtividade e eficiência agronômica do milho em função da adubação nitrogenada e manejos do solo. Revista Brasileira de Milho e Sorgo, 9:135-146.

Ferreira DF (2000) Análises estatísticas por meio do Sisvar para Windows versão 4.0. In: 45 ${ }^{\text {a }}$ Reunião Anual da Região Brasileira da Sociedade Internacional de Biometria, São Carlos. Anais, UFSCar. p.255-258.

Fixen PE, Jiyun J, Tiwari KN \& Stauffer MD (2005) Capitalizing on multi-element interactions through balanced nutrition - A pathway to improve nitrogen use efficiency in China, India and North America. Science in China Series C: Life Sciences, 48:780790

Giotto E (2011) Sistema CR - Campeiro 7.0. Disponível em: <http://www.crcampeiro.net/>. Acessado em: 14 outubro de 2011 .

Grohs DS, Bredemeier C, Mundstock CM \& Poletto N (2009) Modelo para estimativa do potencial produtivo em trigo e cevada por meio do sensor Greenseeker. Engenharia Agrícola, 29:101-112.

Hurtado SMC, Resende AV, Silva CA, Corazza EJ \& Shiratsuchi LS (2009) Variação espacial da resposta do milho à adubação nitrogenada de cobertura em lavoura no cerrado. Pesquisa Agropecuária Brasileira, 44:300-309.

Jakelaitis A, Silva AA \& Ferreira LR (2005) Efeitos do nitrogênio sobre o milho cultivado em consórcio com Brachiaria brizantha. Acta Scientiarum Agronomy, 27:39-46.

Jasper J, Reusch S \& Link A (2009) Active sensing of the N status of wheat using optimized wavelength combination-impact of seed rate, variety and growth stage. In: 7th European conference on precision agriculture, Wageningen. Proceedings, Academic Publishers. p. 23-30.

Jorgensen JR \& Jorgensen RN (2007) Uniformity of wheat yield and quality using sensor assisted application of nitrogen. Precision Agriculture, 8:63-73.

Koppen WP (1948) Climatologia, com un estúdio de los climas de la tierra. México, Fondo de Cultura Econômica. 478p.

Lázaro RL, Costa ACT, Silva KFS, Sarto MVM \& Duarte Júnior JB (2013) Produtividade de milho cultivado em sucessão à adubação verde. Pesquisa Agropecuária Tropical, 43:10-17.

Lobell DB (2007) The cost of uncertainty for nitrogen fertilizer management: a sensitivity analysis. Field Crop Research, 100:210-217.

Maine N, Lowenberg-Deboer J, Nell WT \& Alemu ZG (2010) Impact of variable-rate application of nitrogen on yield and profit: a case study from South Africa. Precision Agriculture, 11:448-463.
Malavolta E (2006) Manual de nutrição mineral de plantas. São Paulo, Ceres. 638p.

Mayfield AH \& Trengove SP (2009) Grain and protein responses in wheat using the $\mathrm{N}$-Sensor for variable rate application. Crop and Pasture Science, 60:818-823.

Miranda RA, Duarte JO \& Garcia JC (2012) Cultivo de milho: Sistema de produção I. Disponível em: <http:// sistemasdeproducao.cnptia.embrapa.br/FontesHTML/Milho/ CultivodoMilho_8ed/mercado.htm>. Acessado em: 02 de agosto de 2013.

Nogara Neto F, Roloff G, Dieckow J \& Motta ACV (2011) Atributos de solo e cultura espacialmente distribuídos relacionados ao rendimento do milho. Revista Brasileira de Ciência do Solo, 35:1025-1036.

Portz G, Molin JP \& Jasper J (2012) Active crop sensor to detect variability of nitrogen supply and biomass on sugarcane fields. Precision Agriculture, 13:33-44.

Povh FP, Molin JP, Gimenez LM, Pauletti V, Molin R \& Salvi JS (2008) Comportamento do NDVI obtido por sensor ótico ativo em cereais. Pesquisa Agropecuária Brasileira, 43:1075-1083.

Raun WR \& Johnson GV (1999) Improving nitrogen use efficiency for cereal production. Agronomy Journal, 91:357-363.

Raun WR, Solie JB, Johnson GV, Stone ML, Mullen RW, Freeman KW, Thomason W \& Lukila E (2002) Improving nitrogen use efficiency in cereal grain production with optical sensing and variable rate application. Agronomy Journal, 98:815-820.

Raun WR, Solie JB, Stone ML, Martin KL, Freeman KW, Mullen RW, Zhang H, Shepers JS \& Johnson GV (2005) Optical sensorbased algorithm for crop nitrogen fertilization. Communications in Soil Science and Plant Analysis, 36:2759-2781.

Santi AL, Amado TJC, Cherubin MC, Martin TN, Pires JL, Della Flora LP \& Basso CJ (2012) Análise de componentes principais de atributos químicos e físicos do solo limitantes à produtividade de grãos. Pesquisa Agropecuária Brasileira, 47:1346-1357.

Singh I, Srivastava IA, Chandna P \& Gupta R (2006) Crop sensors for efficient nitrogen management in sugarcane: Potential and constraints. Sugar Tech, 8:299-302.

Snyder CS \& Bruulsema TW (2007) Nutrient use efficiency and effectiveness in North America: Indices of Agronomic and Environmental Benefit. Norcross, IPNI. 4p.

Soil Survey Staff (2010) Keys to Soil Taxonomy. 11 a ed. Washington, USDA. 338p.

Tedesco MJ, Gianello C, Bissani CA, Bohnen H \& Volkweiss SJ (1995) Análise de solo, plantas e outros materiais. $2^{a}$ ed. Porto Alegre, Universidade Federal do Rio Grande do Sul. 174p.

Tubaña BS, Arnall DB, Walsh O, Chung B, Solie JB, Girma K \& Raun WR (2008) Adjusting midseason nitrogen rate using a sensor-based optimization algorithm to increase use efficiency in corn. Journal of Plant Nutrition, 31:1393-1419. 